\title{
Root and tuber flours to improve nutritional quality in instant noodles
}

\author{
Farinhas de raízes e tubérculos para melhoria da qualidade nutricional em macarrões instantâneos
}

Harinas de raíces y tubérculos para mejorar la calidad nutricional de los fideos instantáneos

Received: 03/20/2021 | Reviewed: 03/26/2021 |Accept: 03/29/2021 | Published: 04/09/2021

Isabela Gava de Souza

ORCID: https://orcid.org/0000-0002-7874-0266 State University of Campinas, Brazil

E-mail: isabela.gava2@gmail.com

Wellington da Silva Oliveira

ORCID: https://orcid.org/0000-0003-0194-4794 Instituto de Tecnologia de Alimentos, Brazil

E-mail: wellingtonoliveira1408@gmail.com

Yoon Kil Chang

ORCID: https://orcid.org/0000-0002-5897-1681

State University of Campinas, Brazil

E-mail: yoonkilch@gmail.com

Helena Teixeira Godoy

ORCID: https://orcid.org/0000-0003-4339-5463 State University of Campinas, Brazil E-mail: helena@fea.unicamp.br

Marcio Schmiele

ORCID: https://orcid.org/0000-0001-8830-1710 Federal University of Jequitinhonha and Mucuri Valleys, Brazil E-mail: marcio.sc@ict.ufvjm.edu.br

Pedro H. Campelo

ORCID: https://orcid.org/0000-0003-1538-7941 Federal University of Amazonas, Brazil E-mail: pedrocampelo@ufam.edu.br

Maria Teresa Pedrosa Silva Clerici

ORCID: https://orcid.org/0000-0002-8445-336X State University of Campinas, Brazil

E-mail:mclerici@unicamp.br

\begin{abstract}
The instant noodle (IN) consumption increased significantly among the pasta. The use of regional products may increase the economic value chain, besides the increase of final product functional properties. The aim of this work was to evaluate the partial replacement of refined wheat flour by purple sweet potato, beet and carrot in IN production. The IN were evaluated regarding the fat content (after frying and rehydration), cooking properties, instrumental texture, antioxidant capacity and glycemic index. The results showed that is possible to do the replacement the wheat flour, between the studied conditions, and achieve an IN with similar characteristics to standard sample, but with higher antioxidant capacity and low glycemic index.
\end{abstract}

Keywords: Healthiness; Beetroot; Purple sweet potato; Carrot; Antioxidant capacity; Glycemic index.

\section{Resumo}

O consumo de macarrão instantâneo (IN) aumentou significativamente entre as massas. A utilização de produtos regionais pode aumentar a cadeia de valor econômico e aumentar as propriedades funcionais do produto final. $\mathrm{O}$ objetivo deste trabalho foi avaliar a substituição parcial da farinha de trigo refinada por batata-doce roxa, beterraba e cenoura na produção de IN. Os IN foram avaliados quanto ao teor de gordura (após fritura e reidratação), propriedades de cocção, textura instrumental, capacidade antioxidante e índice glicêmico. Os resultados mostraram que é possível fazer a substituição da farinha de trigo, entre as condições estudadas, e obter um IN com características semelhantes à amostra padrão, porém com maior capacidade antioxidante e baixo índice glicêmico.

Palavras-chave: Saudabilidade; Beterraba; Batata doce roxa; Cenoura; Atividade antioxidante; Índice glicêmico.

\section{Resumen}

El consumo de fideos instantáneos (IN) ha aumentado significativamente entre las pastas. El uso de productos regionales puede incrementar el valor de la cadena económica, además de las propiedades funcionales del producto final. El objetivo de este fue evaluar la sustitución parcial de la harina refinada de trigo por el camote morado, 
beterraga y zanahoria en la producción de IN. Los IN fueron evaluados en cuanto a su contenido de grasa (después de la fritura y rehidratación), propiedades de cocción, textura instrumental, capacidad antioxidante e índice glicémico. Los resultados mostraron que es posible realizar la sustitución de la harina de trigo, dentro de las condiciones estudiadas, y conseguir IN con características similares a la muestra control, pero con una mayor capacidad antioxidante y bajo índice glicémico.

Palabras clave: Salubridad; Beterraga; Camote morado; Zanahoria; Capacidad Antioxidante; Índice glicémico.

\section{Introduction}

Instant noodles (IN) were originated in Japan in the 1950s and are currently produced in 80 countries. In 2019, approximately 106.4 billion servings of instant noodles have been consumed worldwide, where Asian countries correspond to nearly $80 \%$ of instant noodles consumed (WINA, 2020). The consumption of IN is increasing every year due the affordability, convenience and palatability.

Nowadays, there are several researches to improve the quality of IN through fortification to obtain noodles with high nutritional and desirable eating qualities (Parvin et al., 2020), for example the improvement of flavor and color. One possible alternative might be the use of regional products to provide sensory characteristics to noodles, aside from the addition of functional properties. The use of the roots and tubers reduce waste belong the agro-industrial chain.

The use of ingredients rich in bioactive compounds can be an alternative for the nutritional improvement of foods (Neves et al., 2021; Vilar et al., 2021; Wahanik et al., 2021). Besides the economic value added, the use of roots and tubers in instant noodles may contribute to enrich the population diet by the increase of bioactive compounds in this product, such as with antioxidant capacity. Examples of roots and tubers with high content in antioxidant compounds are purple sweet potato, rich in phenolic compounds with acts on the prevention of chronic noncommunicable diseases (Rodriguez-Amaya et al., 2008); the beetroot which contains the betalain that can act on the cancer prevention and the carrot, rich in $\beta$-carotene (carotenoid). Besides the antioxidant compounds, these roots and tubers are rich in dietary fibers, which prevent diabetes type 2, since they help to reduce the glycemic index (Mello \& Laaksonen, 2009).

The aim of this work was to analyze the technical and nutritional feasibility of the partial refined wheat flour replacement through 5 or $10 \%$ purple sweet potato, beet or carrot flour in instant noodles production in order to analyze the product feasibility.

\section{Methodology}

\subsection{Raw material}

Wheat flour and palm fat were donated by Moinho Paulista (Santos, Brazil) and Bunge (São Paulo, Brazil), respectively. The beet, purple sweet potato and carrot were purchased from the local market in the whole form and processed into flour.

\subsection{Processing of beet, purple sweet potato and carrot flours}

The tuber and roots were washed in potable water, sanitized by immersion in chlorated water $(100 \mathrm{ppm} / 20 \mathrm{~min})$ and washed in potable water again. Pieces with uniform sizes (approximately 50x10 mm) were cut and blanched in boiling water for 5 minutes for poliphenoloxidase inactivation. The blanching process was confirmed by guaiacol test, in the presence of hydrogen peroxide. The material was cooled as the method described by Ortolan (2015). The dehydration was carried out in a LP820 freeze-dryer (Liotop, São Carlos, BRA) for 72 hours. The material was ground in an OBL10/2 Blender (OXY, Santana de Parnaíba, BRA), at 35000 rpm until particle size lower than $500 \mu \mathrm{m}$. 


\subsection{Characterization of raw material}

The flour from wheat (WF), beet (B), purple sweet potato (PSP) and carrot (C) were characterized for fat, ash, protein, total starch and total dietary fiber according to the methods 30-25.01, 08-01.01, 46-13.01 and 76-13.01 and 32-05.01 (AACCI, 2010), respectively.

\subsection{Instrumental color of flours and INs}

Color measurements were performed as described by Pereira et al. (2019).

\subsection{Experimental formulations}

WF corresponds to the $100 \%$ refined wheat flour. 6 blends of WF with substitution of $5 \mathrm{or} 10 \mathrm{~g} / 100 \mathrm{~g}$ of beet, purple sweet potato and carrot flour were prepared in an HB 12 planetary mixer (Hypólito, Ferraz de Vasconcelos, BRA) for 5 minutes at speed 2.

\subsection{Rheological properties}

The samples were evaluated through the farinographic properties (method 54-21.01), extensographic properties (method 54-10.01) (AACCI, 2010), and pasting properties method 162 (ICC, 1996).

\subsection{Elaboration of instant noodles}

The control instant noodle (INWF) (100\% WF)) was elaborated by mixing $500 \mathrm{~g}$ of flour or premix with $10 \mathrm{~g}$ of $\mathrm{NaCl}$. The added water considered was calculated according to the water absorption (WA) from the farinographic analysis, as described by Vernaza et al. (2011). For the INWF was defined $35 \%$ (flour basis) of water addition by pre-tests. Regarding the composite IN, the added water $(\%)$ was proportional to the farinographic analysis for each sample and the added water for the control sample:

$$
\text { added water }(\%)=\frac{(\text { WA composite flour) } \times 35 \%}{\text { WA wheat flour }}
$$

Where: WA is water absorption of wheat flour

Flour, salt and water were mixed for 15 minutes, rest for 5 minutes, laminated up to $1.2 \mathrm{~mm}$ of thickness and cut by roller knife with $0.9 \mathrm{~mm}$ width in the Piuno Nuova equipment (Asti, ITA). The noodles were steamed in an EC-3 combined oven (Prática, Pouso Alegre, BRA). Portions with $80 \mathrm{~g}$ were fried in a conventional fryer (Gastromac, Caxias do Sul, BRA) in palm fat at $150{ }^{\circ} \mathrm{C} / 75 \mathrm{~s}$. The IN were manufactured in duplicate.

\subsection{Characterization of INs}

\subsubsection{Moisture and fat adsorption during process}

The INs after deep-frying were characterized for the moisture and fat adsorption content according to method 4415.02 and 30-25.01 (AACCI, 2010), respectively. 


\subsubsection{Retained fat and fat loss contents after rehydration}

The INs after rehydration were characterized for the retained fat according to method 30-25.01 (AACCI, 2010). Fat loss was measured by the difference between the fat adsorption and the retained fat after rehydration.

\subsubsection{Cooking properties after rehydration}

The INs were rehydrated in boiling water for 3 minutes and analyzed regarding the weight gain (WG) and solid loss (SL), according to the method 66-50.01 (AACCI, 2010).

\subsubsection{In vitro glycemic index after rehydration}

The in vitro glycemic index was performed only for the IN with higher partial WF replacement. The measurement was according to the method described by Leoro et al. (2010) were performed.

\subsubsection{Antioxidant capacity after rehydration}

The IN antioxidant capacity was carried out according the method ORAC (Oxygen Radical Absorbance Capacity) based on the methodology described by Dávalos et al. (2004) and the method ABTS (2,2'-azinobis-(3-ethylbenzothiazoline6-sulfonic acid)) based on the methodology described by Re (1999). For the both methods were used hydrophilic and lipophilic extracts as described by Pertuzatti et al. (2014). Only for the IN with higher partial WF replacement were considered.

\subsection{Statistical Analysis}

The data obtained for the raw materials and for the IN were evaluated using analysis of variance (ANOVA) and comparing means (Tukey test), considering a 0.05 significance level.

\section{Results and Discussion}

\subsection{Chemical composition and instrumental color of raw materials}

Table 1 shows the results of the proximate composition of the wheat flour (WF), beetroot (B), purple sweet potato (PSP) and carrot (C). The WF was found high in protein content and low in ash content, suggesting a good flour for noodles manufacturing and for the development gluten network, since there is no evidence of the outer layer from the wheat grain. $\mathrm{C}$ is a high fiber, sugar and protein content powder. Similar results were obtained by Gazalli et al. (2013) for dried carrot paste in oven at $50{ }^{\circ} \mathrm{C}$. In the case of PSP, starch is the most predominant compound and the starch value is in agreement with those found by Ji et al. (2015) for different varieties of PSP. In addition, the powder is low in fat content and high in fiber content. Fiber content for PSP was found lower in literature around $2.00 \%$ (Ji et al., 2015), but the high content might be explained by the powder manufacturing by lyophilization where there is no heat process involved and can preserve the fiber structure with no breakage of polysaccharide-glycosidic linkage in dietary fiber polysaccharides (Lola, 2009). B exhibited a low content of fat and a high content in protein, fiber and sugar. Regarding the protein level, this value was higher than those reported by Costa et al. (2017) for waste beet powder at around $12.65 \%$. The high level of protein might be explained by the use of fertilizers which are rich in nitrogen. Fiber content was lower found by the same author, but it should be highlighted the use of waste materials i.e. peels and stalks which contain higher fiber content when compared to pulp. 
Research, Society and Development, v. 10, n. 4, e23610414086, 2021

(CC BY 4.0) | ISSN 2525-3409 | DOI: http://dx.doi.org/10.33448/rsd-v10i4.14086

Table 1. Chemical composition of the wheat flour (WF), beetroot (B), purple sweet potato (PSP) and carrot (C).

\begin{tabular}{ccccc}
\hline Component (g/100g) & WF & PSP & B & C \\
\hline Fat $^{1}$ & $1.37 \pm 0.06$ & $0.58 \pm 0.01$ & $0.40 \pm 04$ & $2.70 \pm 0.38$ \\
Ash $^{1}$ & $0.62 \pm 0.02$ & $2.55 \pm 0.05$ & $8.53 \pm 0.38$ & $6.18 \pm 0.01$ \\
Protein $^{1,3}$ & $12.67 \pm 0.36$ & $6.96 \pm 0.50$ & $16.56 \pm 0.22$ & $5.66 \pm 0.14$ \\
Total starch $^{1}$ & $71.23 \pm 4.57$ & $51.68 \pm 3.30$ & $0.71 \pm 0.09$ & $6.65 \pm 0.49$ \\
Total dietary fiber $^{1}$ & $3.80 \pm 0.26$ & $12.39 \pm 0.19$ & $27.85 \pm 0.16$ & $30.81 \pm 0.54$ \\
Sugars $^{1,2}$ & $10.31 \pm 2.05$ & $25.84 \pm 1.50$ & $45.95 \pm 0.21$ & $48.00 \pm 0.37$ \\
\hline
\end{tabular}

${ }^{1}$ Results are expressed as mean \pm standard deviation; ${ }^{1}$ values expressed in dry basis; ${ }^{2}$ value of the difference (100-fat-ash-protein-total starch-total dietary fiber); ${ }^{3}$ the conversion factor considered for wheat flour was 5.7 and 6.25 for the roots and tuber flours. Source: Authors (2021).

Table 2. Instrumental colors of the wheat flour (WF), beetroot (B), purple sweet potato (PSP) and carrot (C).

\begin{tabular}{ccccc}
\hline Parameters $^{1}$ & WF & B & PSP & C \\
\hline $\mathbf{L}^{*}$ & $95.02 \pm 0.62^{\mathrm{a}}$ & $31.83 \pm 1.31^{\mathrm{d}}$ & $48.49 \pm 0.37^{\mathrm{c}}$ & $71.9 \pm 0.80^{\mathrm{b}}$ \\
$\mathbf{a}^{*}$ & $0.71 \pm 0.28^{\mathrm{d}}$ & $34.52 \pm 0.43^{\mathrm{a}}$ & $18.15 \pm 0.62^{\mathrm{c}}$ & $31.89 \pm 0.68^{\mathrm{b}}$ \\
$\mathbf{b}^{*}$ & $10.43 \pm 6.05^{\mathrm{b}}$ & $7.12 \pm 0.58^{\mathrm{c}}$ & $-10.20 \pm 0.26^{\mathrm{d}}$ & $45.23 \pm 1.06^{\mathrm{a}}$ \\
\hline & & & \\
Real color & & & \\
& & & \\
\end{tabular}

${ }^{1}$ Results are expressed as mean \pm standard deviation. Means with different letters in the same row indicate significant differences between samples by Tukey test ( $p$-value $\leq 0.05)$. Source: Authors (2021).

The instrumental color of the flours is shown in the Table 2. The colors were characteristic to the pigments present in each sample. The WF showed a high luminosity due the blanching process after milling. For the other flours, the main pigment responsible for the color is the betalain in B, anthocyanin in PSP and $\beta$-carotene in C.

\subsection{Rheological Properties}

\subsubsection{Farinograph}

The effect on dough rheology properties of the partial WF replacement by 5 and $10 \%$ of roots and tuber flours is presented in Table 3 . The WF presented a high strength of the gluten network due to the high WA ( $\geq 58 \%)$ and stability $(\geq 15$ min) (Schmiele et al., 2017). However, the WA is lower when compared to commercial IN (WA at 64.6\%) and higher to the stability (stability at $12.5 \mathrm{~min}$ ) (Hou, 2010).

It is important to understand the rheological properties to predict the final product quality. The water absorption (WA) of PSP composite flour at $10 \%$ substitution was the highest. WA is the amount of water required which the gluten would have been completely developed. This effect is caused by the characteristic of amylose and amylopectin. (Shan et al., 2013) obtained similar results with the addition of PSP flour to the wheat flour with different levels of substitution. Regarding the $\mathrm{C} 10$ composite flour, which has a considerable amount of fiber when compared to the others, presents a high WA as well. The presence of hydroxyl groups in the fiber structure increases the WA, which enable more water interaction through 
Research, Society and Development, v. 10, n. 4, e23610414086, 2021

(CC BY 4.0) | ISSN 2525-3409 | DOI: http://dx.doi.org/10.33448/rsd-v10i4.14086

hydrogen bonding. Lauková et al. (2016) obtained similar results with the addition of potato dietary fiber to the wheat dough.

Table 3. Farinograph parameters of the wheat flour (WF) and the composite flours.

\begin{tabular}{cccccc}
\hline Sample $^{1}$ & $\begin{array}{c}\text { Arrival time } \\
(\mathbf{m i n})\end{array}$ & $\begin{array}{c}\text { Dough } \\
\text { Stability (min) }\end{array}$ & $\begin{array}{c}\text { Dough } \\
\text { development time } \\
(\mathbf{m i n})\end{array}$ & $\begin{array}{c}\text { Water } \\
\text { absorption (\%) }\end{array}$ & $\begin{array}{c}\text { Mixing } \\
\text { tolerance index } \\
(\text { MTI) (UF) }\end{array}$ \\
\hline WF & $1.16 \pm 0.10^{\mathrm{ab}}$ & $16.77 \pm 0.63^{\mathrm{a}}$ & $12.17 \pm 1.54^{\mathrm{a}}$ & $57.80 \pm 0.16^{\mathrm{e}}$ & $46.00 \pm 4.54^{\mathrm{c}}$ \\
B5 & $1.59 \pm 0.19^{\mathrm{ab}}$ & $11.97 \pm 0.30^{\mathrm{b}}$ & $9.33 \pm 0.28^{\mathrm{b}}$ & $59.53 \pm 0.12^{\mathrm{d}}$ & $65.33 \pm 4.32^{\mathrm{c}}$ \\
B10 & $1.72 \pm 0.08^{\mathrm{a}}$ & $12.27 \pm 0.09^{\mathrm{b}}$ & $9.53 \pm 9.53^{\mathrm{b}}$ & $59.17 \pm 0.09^{\mathrm{d}}$ & $62.67 \pm 9.28^{\mathrm{c}}$ \\
PSP5 & $1.19 \pm 0.30^{\mathrm{b}}$ & $8.97 \pm 0.10^{\mathrm{c}}$ & $7.33 \pm 0.12^{\mathrm{c}}$ & $60.47 \pm 0.17^{\mathrm{c}}$ & $97.67 \pm 5.31^{\mathrm{b}}$ \\
PSP10 & $1.63 \pm 0.10^{\mathrm{ab}}$ & $6.97 \pm 0.33^{\mathrm{d}}$ & $7.00 \pm 0.21^{\mathrm{c}}$ & $65.10 \pm 0.14^{\mathrm{a}}$ & $125.00 \pm 10.70^{\mathrm{a}}$ \\
C5 & $1.46 \pm 0.05^{\mathrm{ab}}$ & $12.33 \pm 0.75^{\mathrm{b}}$ & $9.53 \pm 1.18^{\mathrm{b}}$ & $60.47 \pm 0.29^{\mathrm{c}}$ & $56.33 \pm 4.10^{\mathrm{c}}$ \\
C10 & $1.72 \pm 0.17^{\mathrm{a}}$ & $12.53 \pm 0.12^{\mathrm{b}}$ & $10.20 \pm 0.08^{\mathrm{b}}$ & $62.60 \pm 0.08^{\mathrm{b}}$ & $51.67 \pm 4.50^{\mathrm{c}}$ \\
\hline
\end{tabular}

${ }^{1}$ Results are expressed as mean \pm standard deviation. Means with different letters in the same column indicate statistically significant differences between samples by Scott-Knott test ( $p$-value $\leq 0.05)$. Source: Authors (2021).

From the data obtained, it is observed that WF replaced by roots and tuber flours showed a lower stability time as compared to the WF. It is expected due to the composition of the flours that can dilute gluten proteins and interfere in the gluten network development. The stability time is an important dough quality parameter. Lower is this parameter, the shorter is the dough mixture time without gluten network destruction. As well, the MTI was affected by the partial wheat flour replacement, indicating that the composite flour doughs have a lower tolerance to mechanical action over a prolonged mixing time (Leoro et al., 2010), specially the PSP composite flour.

\subsubsection{Extensograph}

The extensograph properties of the WF and its composite doughs are shown in the Table 4. Through this analysis, it is possible to evaluate the dough stretch resistance and elasticity. The results show that the WF and its composite doughs increased the resistance to extension over the rest time. Comparing the extensographic parameters after $135 \mathrm{~min}$, it is observed that the WF dough had the lowest value for resistance to extension whereas the WF composite dough with $10 \%$ of root flours present the highest value for this parameter. On the other hand, the wheat WF the highest value for extensibility. This suggests that the addiction of the root flours weakened the extensographic properties of the dough probably due to the decrease of wheat gluten content that is interfered by the other compounds from the root flours (starch, fiber). In general, the WF composite dough had great resistance to extension and lower extensibility, resulting in stiffer and denser doughs. 
Research, Society and Development, v. 10, n. 4, e23610414086, 2021

(CC BY 4.0) | ISSN 2525-3409 | DOI: http://dx.doi.org/10.33448/rsd-v10i4.14086

Table 4. Extensograph properties of WF dough and WF composite doughs evaluating the: energy $\left(\mathrm{E}=\mathrm{cm}^{2}\right)$; resistance $(\mathrm{R} 50=\mathrm{EU})$; extensibility $(\mathrm{Ex}=\mathrm{mm})$; maximum resistance $(\mathrm{RM}=\mathrm{EU})$ and ratio $\left(\mathrm{R}=\mathrm{EU} \cdot \mathrm{mm}^{-1}\right)$.

\begin{tabular}{|c|c|c|c|c|c|c|c|c|c|c|c|c|c|c|c|}
\hline & $\mathbf{E}$ & $\mathbf{R 5 0}$ & $\mathbf{E x}$ & $\mathbf{R M}$ & $\mathbf{R}$ & $\mathbf{E}$ & R50 & $\mathbf{E x}$ & $\mathbf{R M}$ & $\mathbf{R}$ & $\mathbf{E}$ & R50 & $\mathbf{E x}$ & $\mathbf{R M}$ & $\mathbf{R}$ \\
\hline & \multicolumn{5}{|c|}{$45 \min$} & \multicolumn{5}{|c|}{$90 \mathrm{~min}$} & \multicolumn{5}{|c|}{$135 \mathrm{~min}$} \\
\hline WF & $\begin{array}{c}116.0^{\mathrm{a}} \\
\pm 4.0\end{array}$ & $\begin{array}{l}412.0^{\mathrm{c}} \\
\pm 40.0\end{array}$ & $\begin{array}{l}151.0^{\mathrm{a}} \\
\pm 13.0\end{array}$ & $\begin{array}{l}595.5^{b} \\
\pm 35.5\end{array}$ & $\begin{array}{l}2.77^{\mathrm{d}} \\
\pm 0.50\end{array}$ & $\begin{array}{c}132.5^{\text {ab }} \\
\pm 4.5\end{array}$ & $\begin{array}{c}588.0^{\mathrm{e}} \\
\pm 2.0\end{array}$ & $\begin{array}{c}131.0^{\mathrm{a}} \\
\pm 1.0\end{array}$ & $\begin{array}{l}792.5^{\mathrm{c}} \\
\pm 36.5\end{array}$ & $\begin{array}{l}4.49^{\mathrm{d}} \\
\pm 0.02\end{array}$ & $\begin{array}{c}144.0^{\mathrm{a}} \\
\pm 7.0\end{array}$ & $\begin{array}{l}643.5^{\mathrm{d}} \\
\pm 17.5\end{array}$ & $\begin{array}{c}133.0^{\mathrm{a}} \\
\pm 3.0\end{array}$ & $\begin{array}{l}861.0^{\mathrm{d}} \\
\pm 30.0\end{array}$ & $\begin{array}{l}4.84^{\mathrm{d}} \\
\pm 0.02\end{array}$ \\
\hline B5 & $\begin{array}{c}106.0^{\mathrm{a}} \\
\pm 6.0\end{array}$ & $\begin{array}{c}511.0^{\mathrm{bc}} \\
\pm 42.0\end{array}$ & $\begin{array}{r}125.5^{\mathrm{b}} \\
\pm 1.5\end{array}$ & $\begin{array}{l}638.0^{\mathrm{b}} \\
\pm 44.0\end{array}$ & $\begin{array}{l}0.20^{\mathrm{e}} \\
\pm 0.02\end{array}$ & $\begin{array}{c}140.0^{\mathrm{a}} \\
\pm 5.0\end{array}$ & $\begin{array}{l}769.0^{\mathrm{d}} \\
\pm 33.0\end{array}$ & $\begin{array}{c}119.0^{\mathrm{ab}} \\
\pm 5.0\end{array}$ & $\begin{array}{l}954.5^{\mathrm{b}} \\
\pm 81.5\end{array}$ & $\begin{array}{l}6.49^{\mathrm{cd}} \\
\pm 0.55\end{array}$ & $\begin{array}{l}151.6^{\mathrm{a}} \\
\pm 13.4\end{array}$ & $\begin{array}{c}837.0^{\mathrm{c}} \\
\pm 5.2\end{array}$ & $\begin{array}{c}117.9^{\mathrm{b}} \\
\pm 8.6\end{array}$ & $\begin{array}{c}1030.7^{\mathrm{cd}} \\
\pm 32.6\end{array}$ & $\begin{array}{l}7.10^{\mathrm{c}} \\
\pm 0.64\end{array}$ \\
\hline B10 & $\begin{array}{l}109.0^{\mathrm{a}} \\
\pm 16.5\end{array}$ & $\begin{array}{l}758.0^{\mathrm{a}} \\
\pm 76.8\end{array}$ & $\begin{array}{c}100.0^{\mathrm{bc}} \\
\pm 5.1\end{array}$ & $\begin{array}{l}824.0^{\mathrm{a}} \\
\pm 84.0\end{array}$ & $\begin{array}{l}7.58^{\mathrm{a}} \\
\pm 0.42\end{array}$ & $\begin{array}{c}135.0^{\mathrm{ab}} \\
\pm 6.0\end{array}$ & $\begin{array}{c}1095.0^{\mathrm{ab}} \\
\pm 73.6\end{array}$ & $\begin{array}{l}96.0^{\mathrm{b}} \\
\pm 7.0\end{array}$ & $\begin{array}{c}1172.0^{\mathrm{a}} \\
\pm 57.5\end{array}$ & $\begin{array}{c}10.88^{\mathrm{ab}} \\
\pm 0.32\end{array}$ & $\begin{array}{l}142.0^{\mathrm{a}} \\
\pm 21.2\end{array}$ & $\begin{array}{c}1308.0^{\mathrm{a}} \\
\pm 69.8\end{array}$ & $\begin{array}{c}86.0^{\text {cd }} \\
\pm 6.1\end{array}$ & $\begin{array}{l}1353.0^{\mathrm{a}} \\
\pm 100.4\end{array}$ & $\begin{array}{l}14.71^{\mathrm{a}} \\
\pm 0.38\end{array}$ \\
\hline PSP5 & $\begin{array}{c}117.0^{\mathrm{a}} \\
\pm 1.5\end{array}$ & $\begin{array}{l}560.0^{\mathrm{b}} \\
\pm 14.5\end{array}$ & $\begin{array}{r}128.0^{\mathrm{b}} \\
\pm 3.0\end{array}$ & $\begin{array}{l}728.0^{\mathrm{ab}} \\
\pm 19.0\end{array}$ & $\begin{array}{l}4.38^{\mathrm{c}} \\
\pm 0.22\end{array}$ & $\begin{array}{c}123.0^{\mathrm{a}} \\
\pm 1.0\end{array}$ & $\begin{array}{c}934.0^{\mathrm{bc}} \\
\pm 60.5\end{array}$ & $\begin{array}{l}99.0^{\mathrm{b}} \\
\pm 16.0\end{array}$ & $\begin{array}{c}1058.0^{\mathrm{ab}} \\
\pm 28.0\end{array}$ & $\begin{array}{l}9.43^{\mathrm{bc}} \\
\pm 1.74\end{array}$ & $\begin{array}{c}123.6^{\mathrm{a}} \\
\pm 6.5\end{array}$ & $\begin{array}{c}950.0^{\mathrm{bc}} \\
\pm 40.9\end{array}$ & $\begin{array}{c}95.2^{\mathrm{bcd}} \\
\pm 5.0\end{array}$ & $\begin{array}{c}1036.6^{\mathrm{cd}} \\
\pm 52.2\end{array}$ & $\begin{array}{l}10.00^{\mathrm{b}} \\
\pm 0.71\end{array}$ \\
\hline PSP10 & $\begin{array}{l}109.0^{\mathrm{a}} \\
\pm 16.5\end{array}$ & $\begin{array}{l}758.0^{\mathrm{a}} \\
\pm 76.8\end{array}$ & $\begin{array}{r}100.0^{\mathrm{c}} \\
\pm 5.1\end{array}$ & $\begin{array}{l}824.0^{\mathrm{a}} \\
\pm 84.0\end{array}$ & $\begin{array}{l}7.58^{\mathrm{a}} \\
\pm 0.42\end{array}$ & $\begin{array}{c}135.0^{\mathrm{ab}} \\
\pm 6.0\end{array}$ & $\begin{array}{c}1095.0^{\mathrm{ab}} \\
\pm 73.6\end{array}$ & $\begin{array}{l}96.0^{\mathrm{b}} \\
\pm 7.0\end{array}$ & $\begin{array}{c}1172.0^{\mathrm{a}} \\
\pm 57.5\end{array}$ & $\begin{array}{c}10.88^{\mathrm{ab}} \\
\pm 0.32\end{array}$ & $\begin{array}{l}141.6^{\mathrm{a}} \\
\pm 21.0\end{array}$ & $\begin{array}{c}1308.0^{\mathrm{a}} \\
\pm 69.8\end{array}$ & $\begin{array}{c}86.0^{\text {cd }} \\
\pm 6.2\end{array}$ & $\begin{array}{l}1353.3^{\mathrm{a}} \\
\pm 100.6\end{array}$ & $\begin{array}{l}14.78^{\mathrm{a}} \\
\pm 0.37\end{array}$ \\
\hline C5 & $\begin{array}{c}115.0^{\mathrm{a}} \\
\pm 5.5\end{array}$ & $\begin{array}{l}535.0^{\mathrm{b}} \\
\pm 42.6\end{array}$ & $\begin{array}{c}131.0^{\mathrm{b}} \\
\pm 2.9\end{array}$ & $\begin{array}{c}635.0^{\mathrm{ab}} \\
\pm 45.4\end{array}$ & $\begin{array}{l}4.08^{\mathrm{c}} \\
\pm 0.43\end{array}$ & $\begin{array}{c}127.0^{\mathrm{ab}} \\
\pm 10.1\end{array}$ & $\begin{array}{c}853.0^{\mathrm{cd}} \\
\pm 71.3\end{array}$ & $\begin{array}{c}108.0^{\mathrm{ab}} \\
\pm 10.7\end{array}$ & $\begin{array}{c}958.0^{\mathrm{bc}} \\
\pm 65.9\end{array}$ & $\begin{array}{l}6.88^{\mathrm{cd}} \\
\pm 0.59\end{array}$ & $\begin{array}{l}152.7^{\mathrm{a}} \\
\pm 15.6\end{array}$ & $\begin{array}{l}990.0^{\mathrm{b}} \\
\pm 46.2\end{array}$ & $\begin{array}{c}106.6^{\mathrm{bc}} \\
\pm 9.3\end{array}$ & $\begin{array}{c}1087.9^{\mathrm{bc}} \\
\pm 70.6\end{array}$ & $\begin{array}{l}9.59^{\mathrm{b}} \\
\pm 1.11\end{array}$ \\
\hline C10 & $\begin{array}{c}109.0^{\mathrm{a}} \\
\pm 2.5\end{array}$ & $\begin{array}{c}628.0^{\mathrm{ab}} \\
\pm 22.5\end{array}$ & $\begin{array}{c}113.0^{\mathrm{bc}} \\
\pm 1.0\end{array}$ & $\begin{array}{l}723.0^{\mathrm{ab}} \\
\pm 36.6\end{array}$ & $\begin{array}{l}5.56^{\mathrm{b}} \\
\pm 0.25\end{array}$ & $\begin{array}{c}127.0^{\mathrm{ab}} \\
\pm 1.2\end{array}$ & $\begin{array}{c}1157.0^{\mathrm{a}} \\
\pm 47.4\end{array}$ & $\begin{array}{l}91.0^{\mathrm{b}} \\
\pm 14.6\end{array}$ & $\begin{array}{c}1194.0^{\mathrm{a}} \\
\pm 44.8\end{array}$ & $\begin{array}{l}12.09^{\mathrm{a}} \\
\pm 1.94\end{array}$ & $\begin{array}{l}131.4^{\mathrm{a}} \\
\pm 11.5\end{array}$ & $\begin{array}{c}1237.0^{\mathrm{a}} \\
\pm 36.6\end{array}$ & $\begin{array}{l}83.9^{\mathrm{d}} \\
\pm 3.4\end{array}$ & $\begin{array}{c}1261.1^{\mathrm{ab}} \\
\pm 57.7\end{array}$ & $\begin{array}{l}15.45^{\mathrm{a}} \\
\pm 0.59\end{array}$ \\
\hline
\end{tabular}

${ }^{1}$ Results are expressed as mean \pm standard deviation. Means with different letters in the same column indicate statistically significant differences between samples by Scott-Knott test (p-value $\leq 0.05)$. EU - Extensographic Unit. Source: Authors (2021).

\subsubsection{Viscoamylographic properties}

The values for the viscoamylographic properties of the WF and its blends are shown in the Table 5. The mean value of PV ranged from 2387.33 to $1162.33 \mathrm{cP}$, corresponding to the WF and PSP10, respectively. Peak viscosity corresponds to the starch capability to swell freely before their breakdown. The results show that WF had the highest value for this parameter because of the high starch content in wheat flour. It is also observed that the higher the level of partial substitution, the lower is the peak viscosity. PSP10 had the lowest value probably due to the high fiber and protein contents.

Retrogradation or setback viscosity is related to the reordering of starch molecules. The lower setback values, the lower is the rate of syneresis and retro gradation. Setback values differs significantly between the samples, especially for the samples of high level of partial wheat replacement. This indicates that the addition of $10 \%$ of roots can improve the dough quality as it decreases the setback value compared to control (WF). 
Research, Society and Development, v. 10, n. 4, e23610414086, 2021

(CC BY 4.0) | ISSN 2525-3409 | DOI: http://dx.doi.org/10.33448/rsd-v10i4.14086

Table 5. Viscoamylographic properties of the WF and its composite flours.

\begin{tabular}{cccccc}
\hline Sample $^{1}$ & PV $(\mathbf{c P})$ & $\mathbf{B V}(\mathbf{c P})$ & $\mathbf{F V}(\mathbf{c P})$ & $\mathbf{S V}(\mathbf{c P})$ & PT $\left.^{\mathbf{0}} \mathbf{C}\right)$ \\
\hline WF & $2387.33 \pm 28.00^{\mathrm{a}}$ & $827.67 \pm 84.72^{\mathrm{a}}$ & $2951.33 \pm 4.71^{\mathrm{a}}$ & $1391.67 \pm 11.19^{\mathrm{a}}$ & $66.58 \pm 1.06^{\mathrm{b}}$ \\
B5 & $2172.00 \pm 23.04^{\mathrm{b}}$ & $821.00 \pm 52.84^{\mathrm{a}}$ & $2629.67 \pm 38.06^{\mathrm{b}}$ & $1278.67 \pm 64.60^{\mathrm{a}}$ & $66.88 \pm 0.87^{\mathrm{ab}}$ \\
B10 & $1178.67 \pm 13.67^{\mathrm{cd}}$ & $427.33 \pm 22.22^{\mathrm{b}}$ & $1561.33 \pm 10.53^{\mathrm{c}}$ & $810.00 \pm 13.64^{\mathrm{b}}$ & $69.62 \pm 0.83 \mathrm{ab}$ \\
PSP5 & $2179.33 \pm 12.28^{\mathrm{b}}$ & $731.00 \pm 26.28 \mathrm{a}$ & $2702.67 \pm 24.72^{\mathrm{b}}$ & $1254.33 \pm 12.12^{\mathrm{a}}$ & $67.15 \pm 0.95^{\mathrm{ab}}$ \\
PSP10 & $1162.33 \pm 22.31^{\mathrm{d}}$ & $348.00 \pm 10.61^{\mathrm{b}}$ & $1636.33 \pm 11.44^{\mathrm{c}}$ & $822.00 \pm 27.09^{\mathrm{b}}$ & $69.88 \pm 0.50^{\mathrm{a}}$ \\
C5 & $2239.00 \pm 27.53^{\mathrm{b}}$ & $859.00 \pm 83.67^{\mathrm{a}}$ & $2655.67 \pm 37.24^{\mathrm{b}}$ & $1275.67 \pm 106.20^{\mathrm{a}}$ & $66.55 \pm 1.74^{\mathrm{b}}$ \\
C10 & $1244.00 \pm 15.62^{\mathrm{c}}$ & $434.33 \pm 29.14^{\mathrm{b}}$ & $1633.67 \pm 22.18^{\mathrm{c}}$ & $824.00 \pm 38.00^{\mathrm{b}}$ & $68.90 \pm 0.55^{\mathrm{ab}}$ \\
\hline
\end{tabular}

${ }^{1}$ Results are expressed as mean \pm standard deviation. Means with different letters in the same column indicate statistically significant differences between samples by Scott-Knott test ( $p$-value $\leq 0.05)$. PV - Peak Viscosity; BV - Breakdown Viscosity; FV - Final Viscosity; SV - Setback Viscosity; PT - Pasting Temperature. Source: Authors (2021).

\subsection{Instant Noodles (IN)}

\subsubsection{Moisture, fat absorption and retained fat in IN during process}

Table 6 shows the moisture, fat absorption and fat loss contents found in the instant noodles production. During the deep-frying process at temperature of $135-160^{\circ}$, the product surface water vaporizes quickly creating a porous spongy structure. The evaporated water will be replaced by the frying oil forming small channels that will support the further rehydration. The instant noodle moisture varied from $2.60 \%$ to $8.95 \%$. According to (Kumobura, 1998), the final moisture product should be less than $10 \%$ in order to provide microbiological stability.

Regarding the fat absorption, the samples obtained values between $22.00 \%$ and $26.06 \%$. Commercial noodles present a fat content ranged from 16-24\% (Wu et al., 2006). In this study, the majority of samples is in this range, except INB10. This effect is probably caused by moisture of the sample and due to the heterogeneous structure formed during the process that may retain a higher fat content. 
Research, Society and Development, v. 10, n. 4, e23610414086, 2021

(CC BY 4.0) | ISSN 2525-3409 | DOI: http://dx.doi.org/10.33448/rsd-v10i4.14086

Table 6. Moisture, fat absorption, retained fat after deep-frying process of the instant noodles; Retained fat, cooking properties (Water gain - WG and soluble solid loss - SSL) and textural characteristics of the instant noodles after rehydration.

\begin{tabular}{|c|c|c|c|c|c|c|c|c|}
\hline & Parameters $^{1}$ & NIWF & NIPSP5 & NIPSP10 & NIB5 & NIB10 & NIC5 & NIC10 \\
\hline \multirow{2}{*}{\multicolumn{9}{|c|}{ After deep- }} \\
\hline & & & & & & & & \\
\hline \multirow[t]{3}{*}{ frying } & Fat absorption (\%) & $23.51 \pm 0.54^{\mathrm{b}}$ & $22.00 \pm 0.54^{\mathrm{c}}$ & $23.26 \pm 0.52^{b}$ & $22.04 \pm 0.02^{\mathrm{c}}$ & $26.06 \pm 0.70^{\mathrm{a}}$ & $24.38 \pm 1.40^{\mathrm{ab}}$ & $23.98 \pm 0.82^{\mathrm{b}}$ \\
\hline & Retained fat $(\%)$ & $15.42 \pm 0.93^{\mathrm{bc}}$ & $13.07 \pm 1.17^{\mathrm{d}}$ & $13.21 \pm 0.57^{\mathrm{d}}$ & $17.36 \pm 0.76^{\mathrm{a}}$ & $17.25 \pm 1.02^{\mathrm{ab}}$ & $17.33 \pm 0.62^{\mathrm{a}}$ & $14.60 \pm 0.25^{\mathrm{c}}$ \\
\hline & Fat loss $(\%)$ & $34.66 \pm 6.54^{\mathrm{bc}}$ & $41.95 \pm 2.70^{\mathrm{ab}}$ & $43.65 \pm 0.59^{a}$ & $40.22 \pm 15.04^{\mathrm{ab}}$ & $21.12 \pm 1.77^{\mathrm{d}}$ & $28.83 \pm 1.91^{\mathrm{c}}$ & $39.10 \pm 2.52^{\mathrm{ab}}$ \\
\hline \multirow{4}{*}{$\begin{array}{c}\text { After } \\
\text { rehydration }\end{array}$} & WG & $151.70 .42^{\mathrm{a}}$ & $133.67 \pm 5.01^{\mathrm{b}}$ & $129.86 \pm 7.31^{\mathrm{b}}$ & $127.10 \pm 12.51^{\mathrm{b}}$ & $154.16 \pm 9.38^{\mathrm{a}}$ & $132.14 \pm 0.45^{b}$ & $138.9 \pm 1.71^{\mathrm{ab}}$ \\
\hline & $\mathrm{SL}(\%)$ & $11.21 \pm 0.26^{\mathrm{c}}$ & $10.77 \pm 1.09^{\mathrm{c}}$ & $11.75 \pm 0.70^{\mathrm{bc}}$ & $13.35 \pm 0.98^{\mathrm{ab}}$ & $14.61 \pm 1.41^{\mathrm{a}}$ & $12.32 \pm 0.46^{\mathrm{bc}}$ & $11.65 \pm 0.98^{b c}$ \\
\hline & Firmness (N) & $1.28 \pm 0.15^{\mathrm{a}}$ & $1.19 \pm 0.16^{\mathrm{a}}$ & $0.48 \pm 0.25^{\mathrm{b}}$ & $1.27 \pm 0.10^{\mathrm{a}}$ & $1.19 \pm 0.16^{\mathrm{a}}$ & $1.18 \pm 0.80^{\mathrm{a}}$ & $1.20 \pm 0.18^{\mathrm{a}}$ \\
\hline & $\begin{array}{c}\text { Adhesiveness } \\
\text { (N.s) }\end{array}$ & $0.055 \pm 0.011^{\mathrm{b}}$ & $0.068 \pm 0.010^{\mathrm{b}}$ & $0.098 \pm 0.013^{\mathrm{a}}$ & $0.057 \pm 0.013^{\mathrm{b}}$ & $0.070 \pm 0.01^{b}$ & $0.061 \pm 0.01^{\mathrm{b}}$ & $0.067 \pm 0.01^{\mathrm{b}}$ \\
\hline
\end{tabular}

${ }^{1}$ Results are expressed as mean \pm standard deviation. Means with different letters in the same column indicate statistically significant differences between samples by Scott-Knott test ( $p$-value $\leq 0.05)$. Source: Authors (2021).

\subsubsection{Color of IN during process}

Table 7 shows the results of instrumental color for the deep-fried IN. Luminosity ( $\mathrm{L}^{*}$ ) was affected by the addition of root and tuber flours in the WF and there significantly difference between the samples. It is observed that the value for $\mathrm{L}^{*}$ decreased with the high partial replacement of the WF. The darkness of the noodles is explained by the presence of their pigments that contributes to the color improvement. In the case of IN that contain $\mathrm{C}$, the darkness might be explained by the oxidation of carotenoids that is affected by the heat.

Table 7. Instrumental colors of IN after deep-frying.

\begin{tabular}{cccc}
\hline Samples $^{1}$ & $\mathbf{L}^{*}$ & $\mathbf{a}^{*}$ & $\mathbf{b}^{*}$ \\
\hline INWF & $61.26 \pm 0.87^{\mathrm{a}}$ & $3.44 \pm 0.24^{\mathrm{e}}$ & $21.3 \pm 1.44^{\mathrm{c}}$ \\
INB5 & $27.42 \pm 1.57^{\mathrm{e}}$ & $25.27 \pm 1.06^{\mathrm{a}}$ & $17.64 \pm 0.91^{\mathrm{d}}$ \\
INB10 & $23.04 \pm 1.8^{\mathrm{f}}$ & $14.3 \pm 1.3^{\mathrm{a}}$ & $14.3 \pm 1.12^{\mathrm{e}}$ \\
INPSP5 & $40.35 \pm 2.15^{\mathrm{c}}$ & $5.92 \pm 14.78^{\mathrm{c}}$ & $5.92 \pm 0.49^{\mathrm{f}}$ \\
INPSP10 & $35.04 \pm 2.05^{\mathrm{d}}$ & $15.36 \pm 0.67^{\mathrm{b}}$ & $1.38 \pm 0.11^{\mathrm{g}}$ \\
INC5 & $59.7 \pm 0.98^{\mathrm{a}}$ & $9.24 \pm 0.96^{\mathrm{d}}$ & $37.13 \pm 1.75^{\mathrm{b}}$ \\
INC10 & $56.62 \pm 2.67^{\mathrm{b}}$ & $14.91 \pm 0.8^{\mathrm{b}}$ & $45.14 \pm 3.86^{\mathrm{a}}$ \\
\hline
\end{tabular}

${ }^{1}$ Results are expressed as mean \pm standard deviation. Means with different letters in the same column indicate statistically significant differences between samples by Scott-Knott test ( $p$-value $\leq 0.05)$. Source: Authors (2021). 
Figure 1. Visual aspect of IN after deep-frying process.

INWF

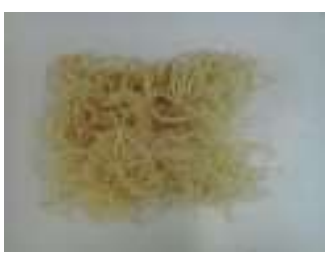

INPSP10
INB5

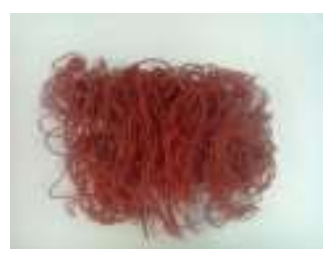

INC5

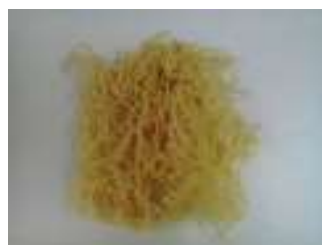

INB10
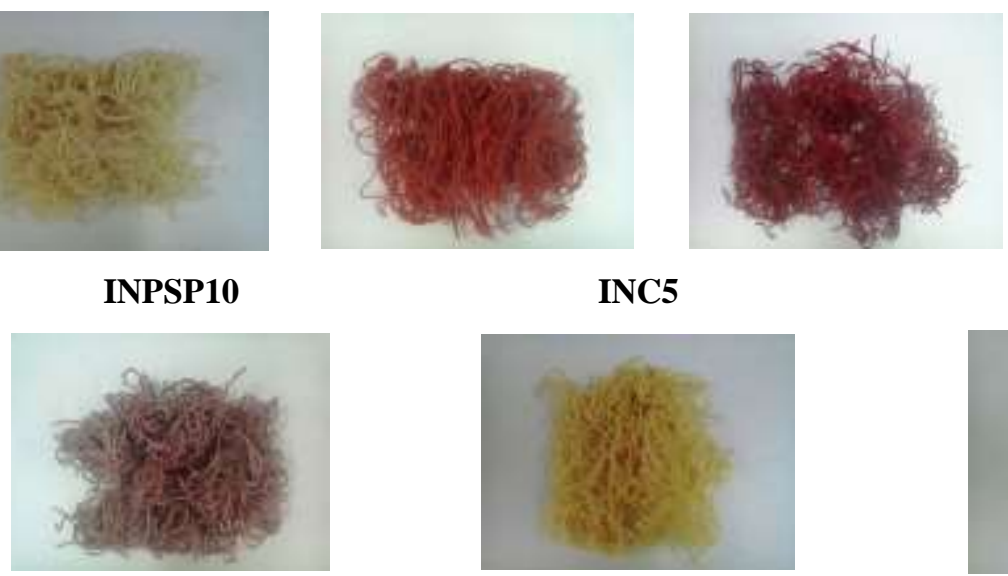

Source: Authors (2021).

\subsubsection{Cooking properties and fat loss in IN after rehydration}

The cooking properties (weigh gain and soluble solid loss) of the deep-fried instant noodles are shown in Table 6. Cooking characteristics of noodles are very important for the consumer market and it will also influence the technological quality of the final product. High level of solid loss is an undesirable characteristic and indicates that the pasta has a low cooking tolerance. Weight gain indicates the ability of the starch-protein structure to absolve water during cooking.

Weight gain ranged from 127.10 to $154.16 \%$, corresponding to samples that contain beetroot. This result is likely due to the high fiber and protein contents in beetroot flour. Similar effect on water absorption were reported by Sipos et al. (2017) after addition of $8 \%$ beet pulp on wheat past.

Solid loss corresponds to loss of starch and other solids from the product during the cooking. It was observed that solid loss increased with the increasing level of root flours replacement in wheat flour. According to Hoseney (1998), cooking loss for a good quality pasta should be lower than $12 \%$. In the case of beetroot product, the high solid loss may due to the high sugar content in this sample and also to the soluble dietary fiber content.

Regarding the fat loss during the rehydration, the majority of the samples presented a higher value when compared to the INWF, representing greater nutritional viability, since IN has a significant amount of residual fat and its consumption causes a great concern for health.

\subsubsection{Glycemic Index of IN after rehydration}

Figure 2 shows the results of the glycemic index of IN. The results show that IN had a lower glycemic index when compared to INWF. INPSP10 and INC10 obtained the lowest value for index glycemic between the samples. This effect might be due to the low digestible starch content in PSP and the high dietary fiber content in C. Studies show that the consumption of products low in glycemic index result in a higher satiety (Brand-Miller et al., 2003). In addition, diets with low glycemic indexes have beneficial effects for the weight control and for the immunity system. 
Figure 2. Glycemic index of instant noodles.

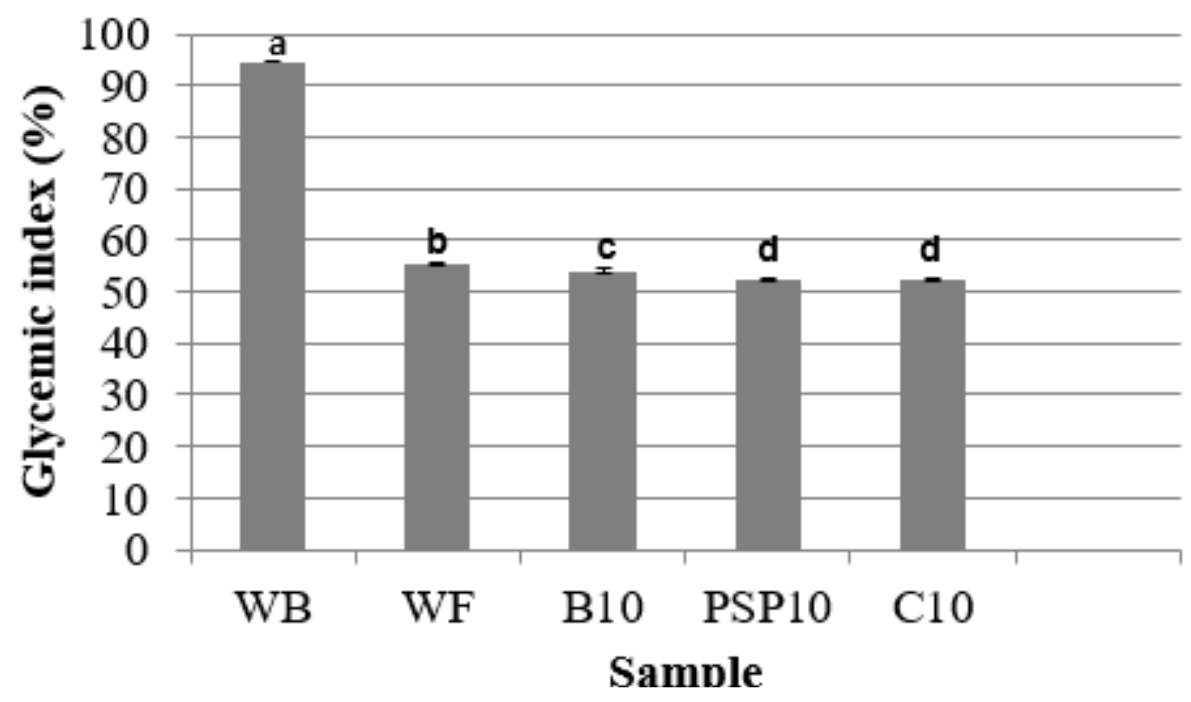

Source: Authors (2021).

\subsubsection{Antioxidant capacity $\mathrm{f}$ IN after rehydration}

Table 8 presents the antioxidant capacity for the ABTS and ORAC methods. It is observed that the hydrophilic extract from ORAC had the highest antioxidant capacity, where INPSP10 showed the highest value. There is no difference between the other samples. Regarding the hydrophilic extract of ABTS method, only the samples INB10 and INPSP10 showed an antioxidant capacity, which INPSP10 was the highest.

Table 8. Antioxidant capacity for hydrophilic and lipophilic extracts of IN in ABTS and ORAC method.

\begin{tabular}{ccccc}
\hline \multirow{2}{*}{ Antioxidant capacity $^{1}$} & \multicolumn{2}{c}{ ABTS } & \multicolumn{2}{c}{ ORAC } \\
\cline { 2 - 5 } & Hydrophilic & Lipophilic & Hydrophilic & Lipophilic \\
\hline WF & $0.04 \pm 0.00^{\mathrm{c}}$ & $2.5 \pm 0.15^{\mathrm{b}}$ & $104.5 \pm 13.98^{\mathrm{b}}$ & $0.05 \pm 0.01^{\mathrm{b}}$ \\
B10 & $1.53 \pm 0.16^{\mathrm{b}}$ & $1.57 \pm 0.08^{\mathrm{d}}$ & $93 \pm 4.7^{\mathrm{b}}$ & $0.05 \pm 0.00^{\mathrm{b}}$ \\
PSP10 & $3.46 \pm 0.21^{\mathrm{a}}$ & $3.38 \pm 0.01^{\mathrm{a}}$ & $191.04 \pm 18^{\mathrm{a}}$ & $0.07 \pm 0.01^{\mathrm{a}}$ \\
C10 & $0.04 \pm 0.00^{\mathrm{c}}$ & $1.9 \pm 0.18^{\mathrm{c}}$ & $105.53 \pm 3.16^{\mathrm{b}}$ & $0.06 \pm 0.00^{\mathrm{ab}}$ \\
\hline
\end{tabular}

${ }^{1}$ Results are expressed as mean \pm standard deviation. Means with different letters in the same column indicate statistically significant differences between samples by Scott-Knott test ( $p$-value $\leq 0.05)$. Source: Authors (2021).

INPSP10 had the highest value for the ABTS method in the lipophilic extracts, followed by INWF and INB10. Regarding the ORAC method, INPSP10 had also the highest antioxidant capacity and did not present significant difference between the others. In addition, the hydrophilic extracts presented a greater antioxidant capacity for ORAC when compared to ABTS. It should be noted the mechanism of both methods is different. The greater antioxidant capacity in hydrophilic extracts compared to the lipophilic extract is due to the presence of bioactive compounds ferulic, synaptic and para-coumaric (Rosa et al., 2013) which are soluble in water.

Regarding the betalains (mainly betacyanins) are water soluble. Due to the antioxidant capacity, pigments that contain nitrogen with high $\mathrm{pH}$ and temperature stabilities might contribute to prevention from age-related diseases (Ravichandran et al., 2013). However, INB10 presented the lowest antioxidant capacity between the samples. Mainly 8 types of anthocyanins 
Research, Society and Development, v. 10, n. 4, e23610414086, 2021

(CC BY 4.0) | ISSN 2525-3409 | DOI: http://dx.doi.org/10.33448/rsd-v10i4.14086

(mainly cyanidin or peonidin) were identified in purple sweet potato (Kano et al., 2005) with different solubility and a high stability which probably explain the better performance obtained in INPSP10 in the antioxidant capacity. In the case of INC10, besides the improvement in $\beta$-carotene bioaccessibility and bioavaiability due to the thermal process, there is a loss of antioxidant capacity because of the isomeration of the molecules (Knockaert et al., 2012).

\section{Conclusion}

The wheat flour replacement through 5 and $10 \%$ of root and tuber flours showed promise results. The use of B, C and PSP had great results regarding the technological properties i.e, cooking properties and instrumental texture. Moreover, the final product with higher WF replacement $(10 \%)$ provide a product with interesting nutritional properties: high antioxidant capacity and low glycemic index. Therefore, they can provide to consumers wellness and wellbeing. It is important to highlight, that the use of roots and tubers can offer different sensory experience for the consumers, especially in terms of color and taste.

\section{Acknowledgments}

The authors are grateful to the Coordination for the Improvement of Higher Education Personnel - Brazil (CAPES) - Finance Code 001, and Conselho Nacional de Desenvolvimento Científico e Tecnológico (CNPq), for the scholarships (Process 150826/2019-2, and 312786/2020-4).

\section{References}

AACCI. (2010). Approved Methods of Analysis. AACC International.

Brand-Miller, J., Hayne, S., Petocz, P., \& Colagiuri, S. (2003). Low-Glycemic Index Diets in the Management of Diabetes: A meta-analysis of randomized controlled trials. Diabetes Care, 26(8), 2261-2267. https://doi.org/10.2337/diacare.26.8.2261

Costa, A. P. D., Hermes, V. S., Rios, A. de O., \& Flôres, S. H. (2017). Minimally processed beetroot waste as an alternative source to obtain functional ingredients. Journal of Food Science and Technology, 54(7), 2050-2058. https://doi.org/10.1007/s13197-017-2642-4

Dávalos, A., Gómez-Cordovés, C., \& Bartolomé, B. (2004). Extending Applicability of the Oxygen Radical Absorbance Capacity (ORAC-Fluorescein) Assay. Journal of Agricultural and Food Chemistry, 52(1), 48-54. https://doi.org/10.1021/jf0305231

Gazalli, H., Malik, A. H., Jalal, H., Afshan, S., \& Mir, A. (2013). Proximate Composition of Carrot Powder and Apple Pomace Powder. International Journal of Food Nutrition and Safety, 3(1), 25-28.

Hoseney, R. C. (1998). Principles of cereal science and technology.

Hou, G. G. (2010). Asian Noodles: Science, Technology and Processing.

ICC, I. A. for C. S. and T. (1996). Rapid Pasting Method. ICC Standard No. 162 (pp. 1-10).

Ji, H., Zhang, H., Li, H., \& Li, Y. (2015). Analysis on the Nutrition Composition and Antioxidant Activity of Different Types of Sweet Potato Cultivars. Food and Nutrition Sciences, 06(01), 161-167. https://doi.org/10.4236/fns.2015.61017

Kano, M., Takayanagi, T., Harada, K., Makino, K., \& Ishikawa, F. (2005). Antioxidative Activity of Anthocyanins from Purple Sweet Potato, Ipomoera batatas Cultivar Ayamurasaki. Bioscience, Biotechnology, and Biochemistry, 69(5), 979-988. https://doi.org/10.1271/bbb.69.979

Knockaert, G., Lemmens, L., Van Buggenhout, S., Hendrickx, M., \& Van Loey, A. (2012). Changes in $\beta$-carotene bioaccessibility and concentration during processing of carrot puree. Food Chemistry, 133(1), 60-67. https://doi.org/10.1016/j.foodchem.2011.12.066

Kumobura, K. (1998). Instant noodles in Japan. Cereal Foods World (pp. 194-197).

Lauková, M., Kohajdová, Z., \& Karovičová, J. (2016). Effect of incorporating potato dietary fibre to wheat dough on the quality of baked rolls. Acta Chimica Slovaca, 9(1), 14-18. https://doi.org/10.1515/acs-2016-0003

Leoro, M. G. V., Clerici, M. T. P. S., Chang, Y. K., \& Steel, C. J. (2010). Evaluation of the in vitro glycemic index of a fiber-rich extruded breakfast cereal produced with organic passion fruit fiber and corn flour. Ciência e Tecnologia de Alimentos, 30(4), 964-968. https://doi.org/10.1590/S010120612010000400019 
Research, Society and Development, v. 10, n. 4, e23610414086, 2021

(CC BY 4.0) | ISSN 2525-3409 | DOI: http://dx.doi.org/10.33448/rsd-v10i4.14086

Lola, A. (2009). The Effect of Boiling on the Nutrients and Anti-Nutrients in Two non Conventional Vegetables. Pakistan Journal of Nutrition, 8(9), 14301433. https://doi.org/10.3923/pjn.2009.1430.1433

Mello, V. D. d., \& Laaksonen, D. E. (2009). Fibras na dieta: tendências atuais e benefícios à saúde na síndrome metabólica e no diabetes melito tipo 2. Arquivos Brasileiros de Endocrinologia \& Metabologia, 53(5), 509-518. https://doi.org/10.1590/S0004-27302009000500004

Neves, E. C. A., Moysés, B. A., Neves, D. A., Campelo, P. H., \& Clerici, M. T. P. S. (2021). Sustainable and regional gastronomy: cassava leaves as a potential ingredient for gluten-free biscuits. Research, Society and Development, 10(3), e12010313071. https://doi.org/10.33448/rsd-v10i3.13071

Parvin, R., Farzana, T., Mohajan, S., Rahman, H., \& Rahman, S. S. (2020). Quality improvement of noodles with mushroom fortified and its comparison with local branded noodles. NFS Journal, 20, 37-42. https://doi.org/10.1016/j.nfs.2020.07.002

Pereira, A. P. A., Clerici, M. T. P. S., Schmiele, M., \& Pastore, G. M. (2019). Blackberries (Rubus sp.) and whole grain wheat flour in cookies: evaluation of phenolic compounds and technological properties. Journal of Food Science and Technology, 56(3), 1445-1453. https://doi.org/10.1007/s13197-019$03628-6$

Pertuzatti, P. B., Barcia, M. T., Rodrigues, D., da Cruz, P. N., Hermosín-Gutiérrez, I., Smith, R., \& Godoy, H. T. (2014). Antioxidant activity of hydrophilic and lipophilic extracts of Brazilian blueberries. Food Chemistry, 164, 81-88. https://doi.org/10.1016/j.foodchem.2014.04.114

Ravichandran, K., Saw, N. M. M. T., Mohdaly, A. A. A., Gabr, A. M. M., Kastell, A., Riedel, H., Cai, Z., Knorr, D., \& Smetanska, I. (2013). Impact of processing of red beet on betalain content and antioxidant activity. Food Research International, 50(2), 670-675. https://doi.org/10.1016/j.foodres.2011.07.002

Re, R. (1999). Antioxidant activity applying an improved ABTS radical cation decolorization assay. In Free Radical Biology and Medicine (pp. 1231-1237).

Rodriguez-Amaya, D. B., Kimura, M., Godoy, H. T., \& Amaya-Farfan, J. (2008). Updated Brazilian database on food carotenoids: Factors affecting carotenoid composition. Journal of Food Composition and Analysis, 21(6), 445-463. https://doi.org/10.1016/j.jfca.2008.04.001

Rosa, N. N., Dufour, C., Lullien-Pellerin, V., \& Micard, V. (2013). Exposure or release of ferulic acid from wheat aleurone: Impact on its antioxidant capacity. Food Chemistry, 141(3), 2355-2362. https://doi.org/10.1016/j.foodchem.2013.04.132

Schmiele, M., Ferrari Felisberto, M. H., Pedrosa Silva Clerici, M. T., \& Chang, Y. K. (2017). Mixolab ${ }^{\mathrm{TM}}$ for rheological evaluation of wheat flour partially replaced by soy protein hydrolysate and fructooligosaccharides for bread production. LWT - Food Science and Technology, 76, 259-269. https://doi.org/10.1016/j.lwt.2016.07.014

Shan, S., Zhu, K.-X., Peng, W., \& Zhou, H.-M. (2013). Physicochemical Properties And Salted Noodle-Making Quality Of Purple Sweet Potato Flour And Wheat Flour Blends. Journal of Food Processing and Preservation, 37(5), 709-716. https://doi.org/10.1111/j.1745-4549.2012.00686.x

Sipos, P., Horváth, M., Adácsi, C., Horváth, B., Babka, B., \& Győri, Z. (2017). Enrichment of pasta products using beetroot. Food Enviroment Safety, 16(4), 209-215.

Vernaza, M. G., Gularte, M. A., \& Chang, Y. K. (2011). Addition of green banana flour to instant noodles: rheological and technological properties. Ciência e Agrotecnologia, 35(6), 1157-1165. https://doi.org/10.1590/S1413-70542011000600016

Vilar, I., Wahanik, A. L., Pastore, G. M., Neri-Numa, I. A., Felisberto, M. H. F., Campelo, P. H., \& Clerici, M. T. P. S. (2021). A ciência de alimentos na sua mesa: o uso da farinha do açafrão como ingrediente rico em antioxidantes para melhoria da saudabilidade em massas frescas integrais. Research, Society and Development, 10(2), e47610211167. https://doi.org/10.33448/rsd-v10i2.11167

Wahanik, A. L., Neri-Numa, I. A., Pastore, G. M., Felisberto, M. H. F., Campelo, P. H., \& Clerici, M. T. P. S. (2021). Technological and antioxidant characteristics of pasta with whole wheat flour and natural colored concentrates. Research, Society and Development, 10(3), e7110312072. https://doi.org/10.33448/rsd-v10i3.13072

WINA, W. instant noodle association. (2020). Expanding market (pp. 1-6).

Wu, J., Aluko, R. E., \& Corke, H. (2006). Partial least-squares regression study of the effects of wheat flour composition, protein and starch quality characteristics on oil content of steamed-and-fried instant noodles. Journal of Cereal Science, 44(2), 117-126. https://doi.org/10.1016/j.jcs.2006.05.008 